\title{
Science classification, visibility of the different scientific domains and impact on scientific development
}

\author{
Classificação das ciências, visibilidade dos diferentes domínios científicos e impacto no \\ desenvolvimento científico \\ Clasificación de las ciencias, la visibilidad de los diferentes campos de la ciencia y el impacto \\ en el desarrollo científico
}

Aida Maria de Oliveira Cruz Mendes*

\begin{abstract}
Background: Science classification is a very important working tool for the organization, evaluation and funding of research and development activities. Based on these ratings, it is possible to obtain data to support strategic decision-making on funding policies, considering criteria of productivity, equity in access, and relationship between investment and outcomes. Science classification systems have evolved over time following the individualization path itself of a particular branch of scientific knowledge and its ability to be recognized by the scientific and social community. Thus, science classification depends on both epistemological and cultural and political criteria.

Objectives and Main topics under analysis: Reflection on the science classification in Portugal and suggestion of alternatives based on other experiences worldwide.

Conclusion: Science classification is a system that reinforces itself, where more power and visibility generate more resources and greater visibility. For this reason, nursing must be recognized as a scientific area and fully develop its social mandate.
\end{abstract}

Keywords: nursing; classification; funding; evaluation

\section{Resumo}

Enquadramento: A classificação das ciências é um instrumento de trabalho muito importante para os processos de organização, avaliação e financiamento das atividades de investigação e desenvolvimento. Com estas classificações é possível obter dados para apoio a tomadas de decisão estratégicas sobre políticas de financiamento, considerando critérios de produtividade, de equidade no acesso e de relação entre o investimento e os resultados produzidos. Os sistemas de classificação das ciências têm evoluído com o tempo acompanhando o próprio trajeto de individualização de um determinado ramo do conhecimento científico e a sua capacidade para se fazer reconhecido pela comunidade científica e social, dependendo tanto de critérios epistemológicos quanto culturais e políticos.

Objetivo e Principais tópicos em análise: Reflexão sobre a classificação das ciências em Portugal e sugestão de alternativas baseadas noutras experiências a nível mundial.

Conclusão: Sendo este um sistema que se autorreforça, em que mais poder e visibilidade gera mais recursos e maior visibilidade, é fundamental que a enfermagem veja reconhecido o seu lugar como área científica para que possa desenvolver cabalmente o seu mandato social.

Palavras-chave: enfermagem; classificação; financiamento; avaliação

* Ph.D., Coordinating Professor, Nursing School of Coimbra, 3046-851, Coimbra, Portugal [acmendes@esenfc.pt].

\section{Resumen}

Marco contextual: La clasificación de las ciencias es una herramienta de trabajo muy importante para la organización, evaluación y financiación de las actividades de investigación y desarrollo. Con estas clasificaciones es posible obtener datos para apoyar la toma de decisiones estratégicas sobre las políticas de financiación, teniendo en cuenta criterios de productividad, de equidad en el acceso y de relación entre la inversión y los resultados producidos. Los sistemas de clasificación de las ciencias han evolucionado con el tiempo acompañando al propio trayecto de la individualización de una determinada rama del conocimiento científico y su capacidad para tener reconocimiento entre la comunidad científica y social de acuerdo con criterios tanto epistemológicos como culturales y políticos.

Objetivos y temas de análisis principales: Reflexión sobre la clasificación de las ciencias en Portugal y sugerencias de alternativas basadas en otras experiencias a nivel mundial.

Conclusión: Este es un sistema que se autorrefuerza, en el que más poder y visibilidad genera más recursos y mayor visibilidad, por lo que es esencial que la enfermería vea reconocido su lugar como área científica para poder desarrollar su objetivo social.

Palabras clave: enfermería; clasificación; financiación; evaluación

Received for publication: 14.06 .16 Accepted for publication: 26.07 .16 


\section{Introduction}

Nursing is considered as a scientific area worldwide, with a well-established international scientific community, organized in scientific associations and higher education academies. Nursing education is provided in higher education institutions, preferably in universities (World Health Organization, Department of Human Resources for Health, 2009) and in different degrees: bachelor, masters, doctoral and post-doctoral programs. Nursing researchers all over the world are organized into mono or multidisciplinary research units and teams. The knowledge produced by this scientific community is published in scientific journals of Nursing (or other scientific areas) according to the typical requirements: double-blind peer review and quality assessment with indexing systems and impact factor. In 2012, a total of 116 Nursing journals could be found in the platform Web of Science Science Citation Index Expanded (Science Citation Index Expanded -Nursing: Journal list, 2012). The knowledge produced in this area is scientifically valid and socially useful, translating into health care practice and technological advances.

Therefore, this area should be properly represented in the science classification systems.

\section{Development}

Science and technology classification is a key research tool for their organization and dissemination. According to the report "Health Research Classification Systems - Current Approaches and Future Recommendations" of the European Science Foundation (ESF, 2011), research classification is the fundamental step to understanding resource flows into research and development (R\&D). These classifications allow monitoring and developing organizational strategies, organizing peer review processes, producing portfolio statistics, and strengthening mechanisms for assessment of research projects and programs.

Therefore, these classification systems are excellent management tools since they allow highlighting the scientific productivity within each area and analyzing the relationship between investment and outcomes. However, this plan can only be achieved if the classification system provides visibility to the different scientific areas, identifying them and dividing them into levels of analysis that are captured by search and statistical analysis engines (usually up to the second level).

In Portugal, this does not apply to Nursing.

\section{Classification systems used in Portugal}

In Portugal, two classification systems are used: the Portuguese Science and Technology Foundation (Fundação para a Ciência éTecnologia, FCT) system, used for the organization of funding and evaluation of research projects and units; and the DeGóis platform system, which is used for curriculum organization. Degóis platform offers one of the curricular formats that is accepted (and promoted) by the FCT to assess researchers.

\section{FCT classification system}

The FCT classification system (FCT, 2012) is organized by scientific domains and scientific areas. Four domains are identified: Life and Health Sciences; Exact Sciences and Engineering; Natural and Environmental Sciences; and Social Sciences and the Humanities. Each of these domains is composed of scientific areas and subareas.

With regard to the Life and Health Sciences domain, five scientific areas are identified: (1) Neurosciences, Aging and Degenerative Diseases; (2) Immunology and Infection; (3) Diagnostic, Therapies and Public Health; (4) Biomedicine; and (5) Experimental Biology.

These scientific areas are divided into several subareas, such as: Neurosciences - Molecular and Cellular; Neurosciences - Systems, Clinical and Behavioral; Biology of Aging; Organs and Systems Degeneration; Immunology and Inflammation; Microbiology and Infection; Epidemiology; among others.

Nursing is not identified in any of these classification levels.

\section{DeGóis Platform classification system}

In turn, the curriculum organization available in the DeGóis platform is based on the one used by the OECD, which follows the Frascati Manual. This Manual (OECD, 2007) identifies six areas: (1) Natural Sciences; (2) Engineering and Technology; (3) Medical and Health Sciences; (4) Agricultural Sciences; (5) Social Sciences; and (6) Humanities. 
The Medical and Health Sciences domain includes the following areas: Basic Medicine; Clinical Medicine; Health Sciences; Medical Biotechnology; and Other Medical Sciences.

According to this system, Nursing is classified as a subarea within Health Sciences, at the third level. This is a classification that provides no visibility, as can be seen in the following description:

3.3 Health sciences: Health care sciences and services (including bospital administration, bealth care financing); Health policy and services; Nursing; Nutrition, Dietetics; Public and environmental bealth; Tropical medicine; Parasitology; Infectious diseases; epidemiology; Occupational health; Sport and fitness sciences; Social biomedical sciences (includes family planning, sexual bealth, psychooncology, political and social effects of biomedical research); Medical etbics; Substance abuse). (OECD, 2007, p. 9)

\section{Critical appraisal of both classification systems}

We are unaware of the methodology used to develop the FCT classification system. However, it is clear that this classification lacks the adequate comprehensiveness or thoroughness to give visibility to the different areas in the Life and Health Sciences domain, which has fewer scientific areas when compared to the other domains.

Furthermore, in the Life and Health Sciences domain, the FCT classification system overvalues fundamental and basic research areas to the detriment of clinical research. In fact, four out of the five scientific areas in this domain can be considered as being dedicated to basic research, as can be deduced from the names of its areas and subareas. With regard to clinical research, it emerges as a subarea of the Diagnostic, Therapies and Public Health area.

In this classification system, Nursing is not identified at any level. As a result, Nursing research units and Nursing research projects must be submitted within other scientific areas, being assessed by teams with little or no peer representation. In addition, the calls for project grants are hardly oriented toward Nursing research foci.

The classification system used by the DeGóis platform, based on the FOS (Field of Science) classification follows an ambiguous classification system with regard to the health sciences domain. The same designations are used both for the domain and the scientific areas (e.g., domain: Health and Medical Sciences; areas: Basic Medicine; Clinical Medicine; Health Sciences). As a result, Nursing researchers' activities, articles and other scientific productivity in this disciplinary area cannot be registered in the DeGóis platform. In fact, the fields used in this platform to indicate the knowledge area at a first level limit the registration to the choice between Natural Sciences, Engineering and Technology, Medical Sciences, Agricultural sciences, Social Sciences, Humanities, or Exact Sciences domains. Given this classification, Nursing productivity has to be registered under the Medical Sciences domain. After indicating this field, the platform offers the following possible scientific areas for registration: Basic Medicine, Clinical Medicine, Health Sciences, Medical Biotechnology, and Other Medical Sciences, as shown in the image below:

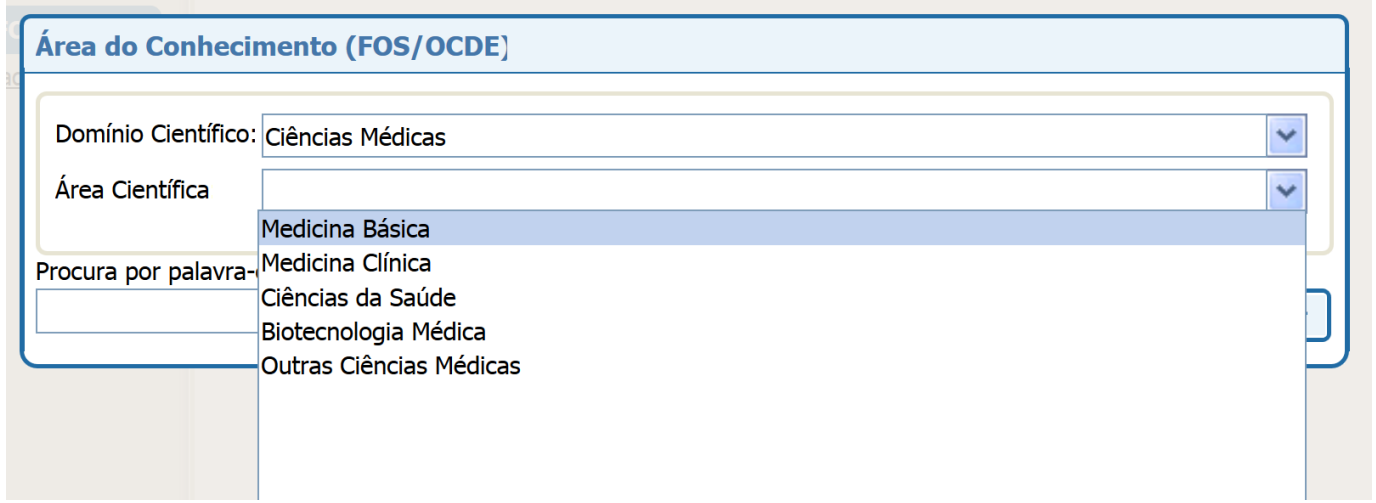

Figure 1. Screenshot: DeGóis Platform, 11 May 2016. 
This classification clearly operates on a misunderstanding that views Health Sciences as a more specific category than Medical Sciences, subordinating all other possibilities to this one and omitting the contribution of the various disciplinary areas to the development of knowledge in the health area.

Health, and the sciences focused on its study, is a broad multidisciplinary field, or, using the FCT terminology, a broad scientific domain. Several areas contribute to its development and understanding. Medical sciences, which are a key, although not exclusive, area within this domain, give a contribution. Other sciences, such as Nursing science, are also important.

The subordination of different health sciences to medical sciences has an historical basis, which is now outdated. In 1979, the UNESCO argued that statistical data organized according to scientific fields should contemplate the domain of medical sciences, including in it several scientific areas, such as Nursing:: (iii) Medical sciences, including: anatomy, dentistry, medicine, nursing, obstetrics, optometry, osteopathy, pharmacy, physiotherapy, public health, other allied subjects (UNESCO, 1979, p. 27).

However, the scientific autonomy of many of those areas is widely recognized today (for example, Pharmacy, which today is Pharmaceutical Sciences). In 2013, the UNESCO acknowledged the autonomy of Nursing in relation to the Medical Sciences:

"Nursing and midwifery" is classified as 0913 and "Medicine" as 0912. Whilst they are closely related there are differences in subject content especially the purpose of learning (doctors and nurses are expected to acquire and apply different knowledge, skills and competencies), methods and techniques and even tools and equipment. There is also a strong interest amongst users of data generated using this classification to be able to differentiate between nurses and doctors. In some countries, doctors and nurses study and qualify at the same levels of education. In these cases, differentiation between them is more easily made through fields than levels of education. (United Nations Educational, Scientific and Cultural Organization, Institute of Statistics [UNESCO], 2013, p. 6)

To sum up, although the autonomy of the Nursing disciplinary field of widely recognized, Nursing has no visibility in the classification systems used in Portugal, preventing Nursing from competing on equal terms with other scientific areas for resource allocation and management. In the FCT classification system, this scientific area is omitted, whereas in the DeGóis platform, its repetition in the designation of different scientific areas removes other areas' visibility.

\section{Other classification systems}

Science is traditionally classified according to domains, areas and subareas. However, the study of the impact and productivity of multiple scientific areas is based on bibliometrics obtained from classification systems. Furthermore, funding and quality control systems depend on the data produced by these classification systems and on the development of well-established scientific communities. For these reasons, many countries have been seeking to create impartial and more transparent classification systems than the ones previously mentioned.

For example, the Academy of Finland has organized its system into two levels: Research field and subfield, in which a three-digit code number is assigned to each field and a four-digit code number is assigned to each subfield (Academy of Finland, 2016). In this classification, 405 is the code for Nursing science, which is different from Biomedicine (401) or Clinical Medicine (407), as shown in the table below. 


\begin{tabular}{|l|l|l|l|}
\hline 401 & Biomedicine & & \\
\hline 402 & $\begin{array}{l}\text { Veterinary } \\
\text { medicine }\end{array}$ & & \\
\hline 403 & Pharmacy & & \\
\hline 404 & Dental science & & \\
\hline 405 & Nursing science & & \\
\hline 406 & $\begin{array}{l}\text { Public health } \\
\text { research }\end{array}$ & & \\
\hline 407 & Clinical medicine & & \\
\hline 408 & Sport sciences & & \\
\hline 409 & Nutrition & & \\
\hline 410 & Environmental \\
health research & & \\
\hline
\end{tabular}

Figure 2. Screenshot: Research field classification, Academy of Finland, http://www. aka.fi/en/funding/how-toapply/applicationguidelines/research-field-classification/.

This type of two-level classification allows capturing and identifying the contribution of different scientific areas. In this classification, the various scientific areas contributing to health are autonomous, and Nursing has a well-deserved research field of its own.

Another example is the Brazilian classification system. In Brazil, the National Council for Scientific and Technological Development (Conselho Nacional de Desenvolvimento Científico e Tecnológico, CNPq) is an agency of the Ministry of Science, Technology and Innovation (Ministério da Ciência, Tecnologia e Inovação, MC\&IT) that aims at promoting science and technology and the training of human resources for research in the country. The CNPq bases its work on a knowledge tree, covering nine major areas, 76 areas and 340 subareas of knowledge. The major areas, which in Portugal correspond to the domains, are Exact and Earth Sciences, Biological Sciences, Engineering, Health Sciences, Agricultural Sciences, Applied Social Sciences, Human Sciences, Linguistics, Languages and Arts, and Others. Health Sciences include the following areas: Medicine, Dentistry, Pharmacy, Nursing, Nutrition, Collective Health, Speech Therapy, Physical Education, Physical Therapy and Occupational Therapy.
The Nursing area (code 40400000) is divided into the following subareas: Adult and Elderly Health Nursing; Women's Health Nursing; Child and Adolescent Health Nursing; Mental Health Nursing; Nursing in Emerging, Reemerging and Neglected Diseases; Nursing in Collective Health; Fundamental Nursing; Nursing in Management and Administration.

The CNPq classification identifies the Health Sciences as a major area, or domain and shows that this is a multidisciplinary domain by identifying different scientific areas integrated in this area, which, in turn, have their own fields of differentiation.

The evolution observed in Brazil allows us to understand the importance of the classification of scientific areas for their own development, as it was recognized in the above mentioned report of the European Science Foundation. In Brazil, the CNPq created the Nursing area in 1981/82. In 2006, as a result of the achievements by this scientific community, the Nursing Advisory Committee (Comité Assessor da Enfermagem, CA-EF) was created. This represented an empowerment and increased accountability for research development and quality (Erdman \& Pagliuca, 2013; Oliveira, Ramos, Barros, \& Nóbrega, 2013). 
Other examples include the Australian system (Australian Bureau of Statistics, 2008), which identifies 22 major areas, namely Medical and Health Sciences (major area, or domain, with code 11). Despite the domain's ambiguous designation, its division into 18 different subareas allows establishing a parallel between the different contributing sciences. Of these 18 different areas, the Nursing area (code 1110) is further divided into 7 subareas: aged care nursing, clinical nursing, primary (preventative), clinical nursing: secondary (acute care), clinical nursing: tertiary (rebabilitative), mental bealth nursing; midwifery; nursing not elsewhere classified.

Another example is the classification system used in the United States of America (The National Academies of Sciences, Engineering, and Medicine, 2006), which adopts a taxonomy of five fields, major areas or domains (Life Sciences; Physical Sciences and Mathematics; Engineering; Social and Behavioral Sciences; and Arts and Humanities). Each of these fields, major areas or domains is divided into subfields or areas. The Life Sciences field is divided into 19 subfields or areas, and Nursing is included at the first level of identification of a scientific domain, at the same level as other health disciplines, such as neuroscience or microbiology.

Finally, it is worth mentioning that the United Kingdom has a unique classification system for Health Sciences - the Health Research Classification System (HRCS). This is a two-dimensional classification system with a transdisciplinary perspective. The first dimension identifies health categories while the second dimension identifies the research activity (from basic to applied research). The intersection of these two dimensions results in multiple possibilities of well-documented research areas (UK Clinical Research Collaboration, 2009).

\section{Conclusion}

The benefits of the classification of scientific areas and their visibility are well documented.

There are multiple classification systems and, to a certain extent, their organization and systematization depends on each scientific community's ability to influence the development of these systems. However, this is a self-strengthening system in which more power and visibility generate more resources and greater visibility. Despite this, the role of the emerging sciences should not be underestimated. For these sciences to be able to fulfill their social mandate, both national and international organizational structures must support and encourage their development.

Nursing is currently recognized as a scientific area; therefore, it must be clearly identified in science classification systems.

\section{References}

Academy of Finland. (2106). Research field classification. Retrieved from http://www.aka.fi/en/funding/how-toapply/application-guidelines/research-field-classification/

Australian Bureau of Statistics. (2008). Australian and New Zealand standard research classification (ANZSRC), 2008. Retrieved from http://www.abs.gov.au/ausstats/abs@.nsf/ 0/6BB427AB9696C225CA2574180004463E

European Science Foundation. (2011). Health research classification systems: Current approaches and future recommendations. Retrieved from http://www.esf.org/ fileadmin/Public_documents/Publications/spb43_Health Research Classification.pdf

Erdmann, A. L., \& Pagliuca, L. M. (2013). O conhecimento em enfermagem: Da representação de área ao Comitê Assessor de Enfermagem no CNPq. Revista Brasileira de Enfermagem, 66(Esp.), 51-59. doi: 10.1590/\$0034-71672013000700007

Fundação para a Ciência e Tecnologia. (2012). Domínios científicos e áreas científicas. Retrieved from https:// www.fct.pt/apoios/projectos/concursos/2012/docs/ Dominios_e_Areas_Cientificas_C2012.pdf

Oliveira, D. C., Ramos, F. R., Barros, A. L., \& Nóbrega, M. M. (2013). Classificação das áreas de conhecimento do CNPq e o campo da Enfermagem: Possibilidades e limites. Revista Brasileira de Enfermagem, 66(Esp.), 60-65. doi: 10.1590/ S0034-71672013000700008

Organisation for Economic Co-operation and Development, Directorate for Science, Technology and Industry, Committee for Scientific and Technological Policy (2007). Revised field of science and technology (FOS) classification in the Frascati manual. Retrieved from http://unstats.un.org/unsd/ EconStatKB/KnowledgebaseArticle10269.aspx

The National Academies of Sciences, Engineering, and Medicine. (2006). Taxonomy list with sub-fields. Retrieved from http:// sites.nationalacademies.org/PGA/Resdoc/PGA_044522

Science citation index expanded -nursing: Journal list. (2012). Retrieved from http://ramsar.mubabol.ac.ir/PDF/ NursingJournals.pdf

United Nations Educational, Scientific and Cultural Organization. (1979). Records of the General Conference: Twentieth session (Vol. 1). Retrieved from http://unesdoc.unesco.org/ images/0011/001140/114032E.pdf 
United Nations Educational, Scientific and Cultural Organization, Institut of Statistics. (2013). International Standard Classification of Education: Fields of education and training 2013: Consultation draft. Retrieved from http://www.uis. unesco.org/Education/Documents/isced-fos-consultationdraft-2013-en.pdf
UK Clinical Research Collaboration. (2009). Health research classification system. Retrieved from http://www.ukcrc.org/ research-coordination/health-research-classification-system/

World Health Organization, Department of Human Resources for Health. (2009). Global standards for the initial education of professional nurses and midwives. Retrieved from http://www.who.int/hrh/nursing_midwifery/hrh_global_ standards_education.pdf 
